\title{
Isolation and identification of alkaloids from Macleaya microcarpa by UHPLC- Q-TOF-MS and their cytotoxic activity in vitro, antiangiogenic activity in vivo
}

\author{
Chunmei Sai ${ }^{1,2}$, Jian'an Wang ${ }^{1}$, Binjie Li ${ }^{3}$, Lin Ding ${ }^{1}$, Huiyun Wang ${ }^{1}$, Qibao Wang ${ }^{1}$, Huiming Hua ${ }^{3}$,
} Fangpeng Zhang ${ }^{2}$ and Qiang Ren ${ }^{1^{*}}$ (1)

\begin{abstract}
Background: Extensive bioactivities of alkaloids from the genus Macleaya (Macleaya cordata (Willd.) R. Br. and Macleaya microcarpa (Maxim.) Fedde) have been widely reported, as well as more and more concerned from the scientific communities. However, systematic research on the phytochemical information of M. microcarpa is incomplete. The aim of this study was to rapidly and conveniently qualitative analyze alkaloids from M. microcarpa by ultra-performance liquid chromatography/quadrupole-time-of-fight mass spectrometry (UHPLC-Q-TOF-MS) using accurate mass weight and characteristic fragment ions, furthermore separate and identify the main alkaloids, test antitumor activity in vitro and antiangiogenic activity in vivo.
\end{abstract}

Results: A total of 14 alkaloids from fruits of M. microcarpa were identified by UHPLC-Q-TOF-MS, including 5 protopines, 2 benzophenanthridines, 1 dimer, 1 dihydrobenzophenanthridines and 5 unknown structure compounds. Two major alkaloids were isolated by various column chromatographic methods. Their structures were determined by NMR data and related literatures. The two major alkaloids were evaluated for intro cytotoxic activities against HL-60, MCF-7, A-549, and in vivo antiangiogenic activity using transgenic zebrafish.

Conclusions: Current qualitative method based on UHPLC-Q-TOF-MS technique provided a scientific basis for isolation, structural identification, and in vitro or in vivo pharmacological further study of alkaloids from M. microcarpa in the future.

Keywords: Macleaya microcarpa, Alkaloids, Isolation and identification, UHPLC-Q-TOF-MS, Biological activity

\section{Introduction}

The genus Macleaya contains two species, Macleaya cordata (Willd.) R. Br. and Macleaya microcarpa (Maxim.) Fedde, which mainly distributed in Japan, South and Northwest China, on slopes of grass or thickets at altitudes of 450-1600 m [1]. They are well-known for their

\footnotetext{
*Correspondence: ren2323@163.com

${ }^{1}$ College of Pharmacy, Jining Medical University, Rizhao 276826,

Shandong, China

Full list of author information is available at the end of the article
}

very extensive application value and great exploitation foreground as well as pesticide, veterinary drug, medicinal ones in North America, Europe, China, which are directly associated with the multifarious alkaloids and their significant biological activities. A variety of alkaloids from $M$. cordata, such as sanguinarine, chelerythrine, protopine, allocryptopine, and others, exhibit anti-microbial, anti-inflammatory, insecticidal, analgesic, anticancer activity, have irreplaceable pharmacological 
effects [2-4]. However, systematic researches on the phytochemical composition of $M$. microcarpa are few.

UHPLC-Q-TOF-MS is widely used in qualitative compositions. The method can provide high resolution and accuracy data, as well as abundant structural information such as high-resolution second-stage mass fragment ions $[5,6]$. This study aimed to rapidly and conveniently characterize alkaloids from $M$. microcarpa by UHPLCQ-TOF-MS using accurate mass weight and characteristic fragment ions, furthermore separate and identify the main alkaloids by chromatographic and spectral techniques, test antitumor activity in vitro using the trypan blue method and MTT method reported previously [7], and antiangiogenic activity in vivo using transgenic zebrafish [8].

\section{Materials and methods \\ Plant materials}

The fruits of Macleaya microcarpa (Maxim.) Fedde were collected from Xiaguan Town, Neixiang County, Nanyang, Henan Province, China, in September 2017. (Notes: It was not a protective plant and was allowed to be collected). It was identified by Prof. Jian'an Wang (College of Pharmacy, Jining Medical University, Shandong, China). The voucher sample (XGBLH-20170918) was deposited in pharmaceutical experimental center, College of Pharmacy, Jining Medical University, Rizhao, China.

\section{Chemicals and reagents}

Chromatographic grade acetonitrile was purchased from Honeywell, Burdick \& Jackson. LC/MS-grade acetonitrile was purchased from Mallinckrodt Baker, Inc. (Phillipsburg, NJ, USA). Chromatographic grade formic acid was purchased from TEDIA, Inc (Fairfield, USA). Deionized water was purified by Millipore purification system (Millipore, MA, USA). Column chromatography (CC) was performed with silica gel (100-200 and 200-300 mesh, Shanghai Taitan Chemical Co. Ltd., Shanghai, China) and mci gel CHP20/P120 (Mitsubishi chemical corporation, Japan) and Sephadex LH-20 (GE Healthcare, Sweden). TLC analysis was carried out with glass plate precoated silica gel $\left(\mathrm{HSGF}_{254}\right.$, Yantai Jiangyou Silicone Development Co. Ltd., Qingdao, China).

\section{Sample preparation}

The air-dried and crushed fruits of $M$. microcarpa $(15.0 \mathrm{~kg})$ were extracted with $95 \% \mathrm{EtOH}(18 \mathrm{~L})$ under cold maceration 3 times, each time for 7 days, respectively. The combined extracts were concentrated in vacuo to yield crude ethanol extracts, which was suspended in $\mathrm{H}_{2} \mathrm{O}$, successively partitioned with Petroleum ether (PE), Methylene chloride $\left(\mathrm{CH}_{2} \mathrm{Cl}_{2}\right)$ and $N$-butyl alcohol
(n-BuOH), to afford $\mathrm{PE}, \mathrm{CH}_{2} \mathrm{Cl}_{2}, n-\mathrm{BuOH}$ and aqueous extracts (For further separation and purification).

The crude ethanol extracts $(200 \mathrm{mg})$ was dissolved with $5 \mathrm{~mL}$ methanol by sonication at $200 \mathrm{~W}$ for $15 \mathrm{~min}$. The solution was filtered with a $0.22 \mu \mathrm{m}$ and then analyzed by UHPLC-Q-TOF-MS.

\section{UPLC-Q-TOF-MS analysis}

Agilent 1290 series Rapid Resolution LC system was coupled with Agilent 6530 Accurate-Mass quadrupole time of flight (Q-TOF) mass spectrometer (Agilent Technologies, CA, USA) equipped with an electrospray ionization (ESI) interface. The chromatographic separation of analyzed crude ethanol extracts was performed on TOSOH TSK gel ODS-100V $(4.6 \times 150 \mathrm{~mm}, 3.0 \mu \mathrm{m})$ column (Tosoh Bioscience, Japan). The column temperature was maintained at $35{ }^{\circ} \mathrm{C}$. The injection volume was $5 \mu \mathrm{L}$. The mobile phase consisted of $0.05 \%$ formic acid $(v / v)(\mathrm{A})$ and acetonitrile $(\mathrm{ACN})(\mathrm{B})$. The gradient program was applied as follows: $0-5 \mathrm{~min}$ at $30 \% \mathrm{~B} ; 5-20 \mathrm{~min}$ at $30-54 \% \mathrm{~B} ; 20-23 \mathrm{~min}$ at $54-70 \% \mathrm{~B} ; 23-40 \mathrm{~min}$ at $70-80 \% \mathrm{~B} ; 40-50 \mathrm{~min}$ at $80-90 \% \mathrm{~B} ; 50-52 \mathrm{~min}$ at $90-30 \%$ B; $52-60 \mathrm{~min}$ at $30 \% \mathrm{~B}$. The flow rate was adjusted to $1.0 \mathrm{~mL} / \mathrm{min}$. The outlet of UHPLC was split (1:4) and introduced into the ESI source.

The MS conditions were set as follows: drying gas at a flow rate of $10 \mathrm{~L} / \mathrm{min}$; drying gas temperature, $350{ }^{\circ} \mathrm{C}$; pressure of nebulizer gas pressure, 45 psig; capillary voltage $( \pm) 3000 \mathrm{~V}$ positive and negative ion modes and the mass range from $m / z 100$ to $1200 \mathrm{Da}$. The MS/MS spectra were acquired with auto MS/MS mode at the acquisition rate of 2 spectra/s.

The calculation of the elemental composition was acquired with Mass Hunter Workstation Software (Qualitative Analysis Version B.06.00) (Agilent Technologies, CA, USA).

\section{Isolation of two major alkaloids}

The dichloromethane extract (365 g) was fractioned using silica gel column chromatography (CC) and eluted with petroleum ether $\left(60-90{ }^{\circ} \mathrm{C}\right)$-ethyl acetate $(100: 5$, 100:10, 100:20, 100:50, 1:1 and 0:100, v/v) to yield six fractions (Fr.A-Fr.F). Fr E was subjected to Sephadex LH-20 eluting with $\mathrm{CH}_{2} \mathrm{Cl}_{2}-\mathrm{MeOH}$ (1:1), and further recrystallization to yield compounds 2 (prtopine, $40 \mathrm{mg}$ ). The precipitate during extraction of dichloromethane was separated by mci gel CHP20P CC eluting with $\mathrm{MeOH}-\mathrm{H}_{2} \mathrm{O}$ (85:15) to afford compound 7 (chelerythrine, $30 \mathrm{mg}$ ).

\section{NMR spectral analysis}

${ }^{1} \mathrm{H}$ and ${ }^{13} \mathrm{C}$ NMR spectra were acquired with Bruker AV-600 NMR spectrometer (Billerica, MA, USA) using 

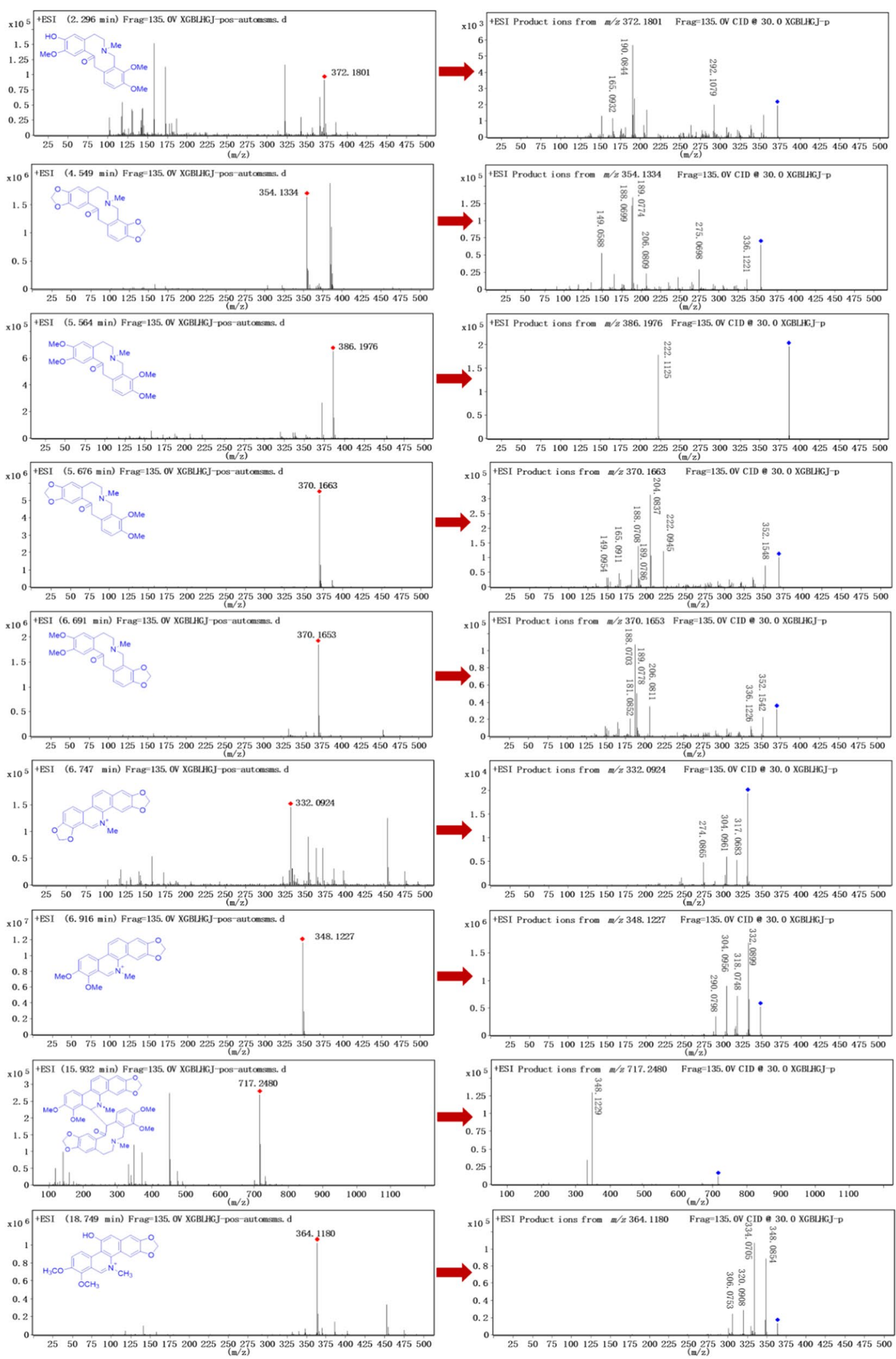

Fig. 1 The high resolution mass spectra and secondary mass spectra for 9 known compounds 


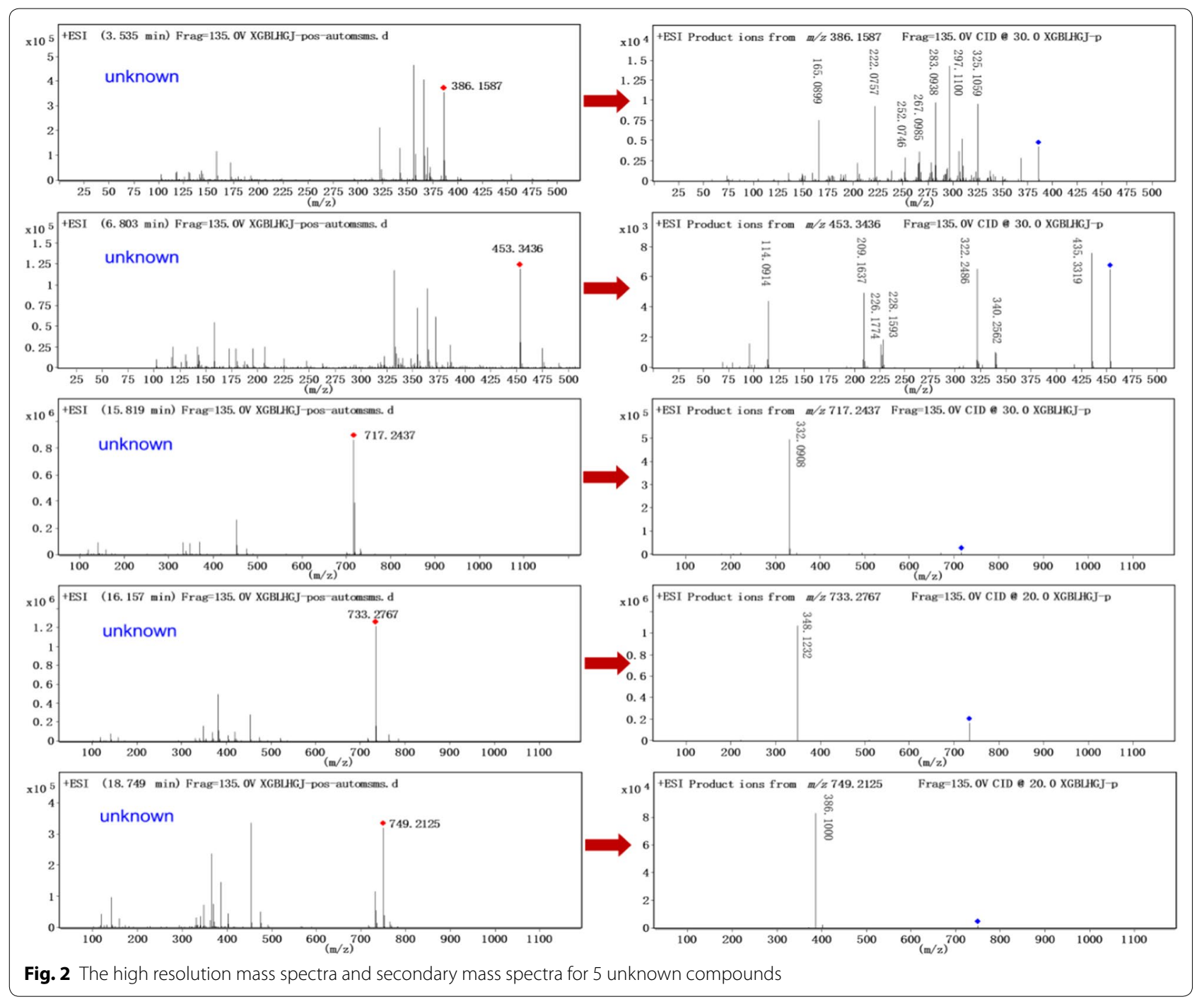

solvent signals $\left(\mathrm{CDCl}_{3}: \delta_{\mathrm{H}} 7.26 / \delta_{\mathrm{C}} 77.16, \mathrm{CD}_{3} \mathrm{OD}: \delta_{\mathrm{H}}\right.$ $3.31 / \delta_{\mathrm{C}} 49.00$ ), with tetramethylsilane (TMS) as an internal standard.

\section{Cytotoxic activity test in vitro}

The method of cytotoxic activity test in vitro had based on our previously published work [9]. HL-60 (human leukaemia cell lines), MCF-7 (human breast cancer cell lines), A-549 (human lung adenocarcinoma cell lines), which were purchased from America Type Culture Collection, ATCC (Rockville, MD, USA) and cultured in RPMI-1640 medium (Gibco, New York, NY, USA) supplemented with $100 \mathrm{U} / \mathrm{mL}$ penicillin, $100 \mathrm{mg} / \mathrm{mL}$ streptomycin, $1 \mathrm{mM}$ glutamine and $10 \%$ heat-inactivated fetal bovine serum (Gibco) at $37^{\circ} \mathrm{C}$ in humidified atmosphere with 5\% $\mathrm{CO}_{2}$. Compounds 2 and 7 were evaluated for cytotoxic activities by the trypan blue method against
HL-60, and MTT assay against MCF-7 and A-549 [10, $11]$.

In the trypan blue method, cells in logarithmic growth were seeded at $5 \times 10^{4}$ cells $/ \mathrm{mL}$ in 24-well microplates, $2 \mathrm{~mL} /$ well, and incubated with various concentrations of the compounds at $37^{\circ} \mathrm{C}$ for $72 \mathrm{~h} .50 \mu \mathrm{L}$ suspension was taken from each well, and $50 \mu \mathrm{L} 0.4 \%$ trypan blue was added to mix well, and observed under an optical microscope within $3 \mathrm{~min}$. Trypan blue-stained (nonviable) cells and the total cell number were determined with a hematocytometer. The growth inhibition in cells after treatment with different concentrations was calculated comparing with control cells (5-Fluorouracil was used as a positive control), and a half growth inhibitory concentration $\left(\mathrm{IC}_{50}\right)$ was obtained by regression analysis of the concentration response data.

In the MTT assay, briefly, cells suspensions, $100 \mu \mathrm{L}$, at a density of $2.5 \times 10^{4}$ cells $/ \mathrm{mL}$, were plated in 96-well 
Table 1 UHPLC-Q-TOF-MS data of identified alkaloids from fruits of $\boldsymbol{M}$. microcarpa

\begin{tabular}{|c|c|c|c|c|c|c|c|}
\hline Peak no. & $T_{\mathrm{R}}(\min )$ & $\begin{array}{l}\text { Theoretical } \\
\text { mass }(m / z)\end{array}$ & Molecular formula & Error (ppm) & $\begin{array}{l}\text { Observed } \\
\text { mass } \\
(\mathrm{m} / \mathrm{z})\end{array}$ & Fragment ions of $M S^{2}(m / z)$ & Identified compounds \\
\hline 1 & 2.296 & 372.1805 & $\mathrm{C}_{21} \mathrm{H}_{25} \mathrm{NO}_{5}$ & 1.21 & 372.1801 & $\begin{array}{l}165(20), 181(10), 190(100), 191(24) \\
192(42), 208(29), 338(12), 354(23), \\
372(35)\end{array}$ & Demethylatedmuramine \\
\hline 2 & 4.549 & 354.1336 & $\mathrm{C}_{20} \mathrm{H}_{19} \mathrm{NO}_{5}$ & 0.56 & 354.1334 & $\begin{array}{l}149(39), 165(17), 188(90), 189(100) \\
190 \text { (7), } 206(17), 336(11)\end{array}$ & Protopine \\
\hline 3 & 5.564 & 386.1962 & $\mathrm{C}_{22} \mathrm{H}_{27} \mathrm{NO}_{5}$ & -3.64 & 386.1976 & $222(91), 386(100)$ & Muramine \\
\hline 4 & 5.676 & 370.1649 & $\mathrm{C}_{21} \mathrm{H}_{23} \mathrm{NO}_{5}$ & -3.79 & 370.1663 & $\begin{array}{l}149(10), 165(15), 188(34), 189(44) \\
190(9), 204(100), 222(37), 352(22)\end{array}$ & Allcryptopine \\
\hline 5 & 6.691 & 370.1649 & $\mathrm{C}_{21} \mathrm{H}_{23} \mathrm{NO}_{5}$ & -1.09 & 370.1653 & $\begin{array}{l}165(15), 181(19), 188(100), 189(47) \\
190(9), 206(32), 336(11), 352(21)\end{array}$ & Cryptopine \\
\hline 6 & 6.747 & 332.0923 & $\mathrm{C}_{20} \mathrm{H}_{14} \mathrm{NO}_{4}$ & -0.35 & 332.0924 & $274(24), 304(30), 317(27), 332(100)$ & Sanguinarine \\
\hline 7 & 6.916 & 348.1236 & $\mathrm{C}_{21} \mathrm{H}_{18} \mathrm{NO}_{4}$ & 2.54 & 348.1227 & $\begin{array}{l}290(20), 304(53), 318(42), 332(100) \\
\quad 333(39), 348(31)\end{array}$ & Chelerythrine \\
\hline 8 & 15.932 & 717.2807 & $\mathrm{C}_{42} \mathrm{H}_{40} \mathrm{~N}_{2} \mathrm{O}_{9}$ & 1.34 & 717.2797 & $348(100), 349(5)$ & $( \pm)$-Macleayin G \\
\hline 9 & 18.749 & 364.1185 & $\mathrm{C}_{21} \mathrm{H}_{18} \mathrm{NO}_{5}{ }^{+}$ & 1.37 & 364.1180 & $\begin{array}{l}306(23), 320(26), 334(100), 348(16) \\
\quad 349(82), 364(12)\end{array}$ & Dihydrochelirubine \\
\hline 10 & 3.535 & & & & 386.1587 & $\begin{array}{l}165(52), 204(15), 222(65), 252(20) \\
266(16), 267(25), 283(68), 306(26) \\
309(37), 325(66), 386(29)\end{array}$ & Unknown \\
\hline 11 & 6.803 & & & & 453.3436 & $\begin{array}{l}435(100), 114(58), 209(65), 226(20) \\
227(10) 228(24), 322(86), 340(13), \\
453(86)\end{array}$ & Unknown \\
\hline 12 & 15.819 & & & & 717.2437 & $332(100), 717$ (2) & Unknown \\
\hline 13 & 16.157 & & & & 733.2767 & $348(100), 733(15)$ & Unknown \\
\hline 14 & 18.749 & & & & 749.2125 & $386(100), 749(2)$ & Unknown \\
\hline
\end{tabular}

microtiter plates and incubated for $24 \mathrm{~h}$ at $37^{\circ} \mathrm{C}$. Then the test compounds with different concentrations in DMSO, $100 \mu \mathrm{L}$, were placed into each microtiter plates and further incubated for $72 \mathrm{~h}$. Finally, $50 \mu \mathrm{L}$ of a $0.4 \%$ MTT solution was added to each well and incubated for $4 \mathrm{~h}$. Then, the MTT was removed from the wells and the formazan crystals were dissolved in DMSO $(200 \mu \mathrm{L})$ for 10 min with shaking. Then the plate was read immediately on a microtiter plate reader (Bio-RAD) at a wavelength of $570 \mathrm{~nm}$ to record the optical density (OD). The $\mathrm{IC}_{50}$ value was defined as the concentration of the control in the MTT assay. 5-Fluorouracil (5-Fu) was used as a positive control. All the $\mathrm{IC}_{50}$ results were expressed as average of three independent experiments.

\section{Antiangiogenic activity test in vivo}

Transgenic Tg (flk: EGFP) zebrafish was provided by drug screening laboratory, Biology Institute of Shangdong Academy of Sciences. PTK787 was provided by biochemistry laboratory, Biology Institute of Shangdong Academy of Sciences (20110902).
Angiogenesis plays a critical role in cancer growth and metastasis. Antiangiogenesis is an excellent target in cancer treatment. In recent assays, the zebrafish model is practical and efficient in vivo model in screening natural product and drug for anti-angiogenesis. [12, 13].

\section{Zebrafish embryo collection}

Male and female transgenic Tg (flk: EGFP) zebrafish were fed separately, and regularly fed with artificial pellet bait and newly hatched Artemia nauplii, stocks were maintained in a controlled environment at $28.5{ }^{\circ} \mathrm{C}$ on a $14 \mathrm{~h}: 10 \mathrm{~h}$ light/dark cycle. Healthy sexual mature zebrafish were put into the same mating cylinder in 1:1 ratio of male and female. Fertilized eggs were obtained at am 9-10 the following day. After disinfection and washing, the fertilized eggs were transferred to embryo water (containing $5.0 \mathrm{mM} \mathrm{NaCl}, 0.17 \mathrm{mM} \mathrm{KCl}, 0.4 \mathrm{mM} \mathrm{CaCl}_{2}$, $0.16 \mathrm{mM} \mathrm{MgSO}_{4}$ ), and cultured at $28^{\circ} \mathrm{C}$. 


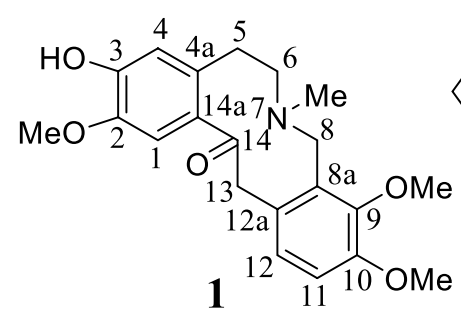<smiles>CN1CCc2cc3c(cc2C(=O)Cc2ccc4c(c2C1)OCO4)OCO3</smiles><smiles>COc1cc2c(cc1OC)C(=O)C(Cc1ccc(OC)c(OC)c1CN(C)C)C2</smiles><smiles></smiles><smiles>COc1cc(CCN(C)Cc2c(CN(C)C)ccc3c2OCO3)c(C(=O)O)cc1OC</smiles><smiles>C[n+]1cc2c3c(ccc2c2c1=CC=C1OCOC1=CC=2)OCO3</smiles><smiles>COc1ccc2c(c[n+](C)c3c4cc5c(cc4ccc23)OCO5)c1OC</smiles>

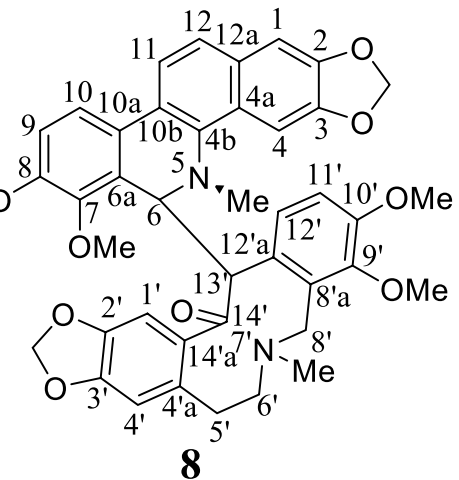<smiles>COc1cc2c(c3c1-c1ccc4cc5c(cc4c1N(C)C3)OCO5)OCO2</smiles>

Fig. 3 Structures of compounds $\mathbf{1 - 9}$

\section{Zebrafish embryo antiangiogenesis assay}

Healthy and limpid embryos were picked out at $24 \mathrm{~h}$ postfertilization (hpf) and distributed into a 24-well microplate (6-8 embryos/well) in $1 \mathrm{~mL}$ Holtfreter's solution and maintained at $28{ }^{\circ} \mathrm{C}$. The sample solution was diluted with embryo water to different concentrations of $0.5,1$, $10,100 \mu \mathrm{g} / \mathrm{mL}$, and added into the well. The final volume of each well was $2.0 \mathrm{~mL}$, and the content of DMSO in each well was adjusted to be consistent. $2.0 \mathrm{~mL} 0.1 \mu \mathrm{g} / \mathrm{mL}$ PTK787 solution served as positive controls. The embryo water or DMSO $(0.5 \%, \mathrm{~V} / \mathrm{V})$ served as blank controls. Embryos were maintained in incubator at $28^{\circ} \mathrm{C}$ for additional $48 \mathrm{~h}$, placed onto a glass slide, photographed using SZX16 fluorescence stereomicroscope and DP2-BSW image acquisition system (Olympus, Japan) after anesthesia. Zebrafish somite intersegmental vessels (ISVs) were quantified using Image Pro Plus software. Anti-angiogenic effects were defined as decrease of SIVs length [14].

\section{Statistical analysis}

SPSS 13.0 was used for statistical analysis, and independent sample $t$ test was used to compare the differences among the groups. $\mathrm{P}<0.05$ was considered as significant difference.

The qualifications and experience of the researcher met the experimental requirements, after the review by the ethics committee of Jining Medical University, and the research design conformed to the principles of scientific science and medical ethics (Ethical code 2019-YX-256).

\section{Results and discussion}

Analysis of alkaloids from fruits of $M$. microcarpa by UHPLC-Q-TOF-MS

In this study, UHPLC-Q-TOF-MS technology was used to qualitative analyzed and identified alkaloids from fruits of M. microcarpa. The high resolution mass spectra and secondary mass spectra are shown in Figs. 1 and 2. These compositions are summarized along with their retention time, theoretical mass, molecular formula, observed mass, error and MS/MS fragments combined with literature reports $[15,16]$ and previously isolated alkaloids from $M$. cordata $[7,9,17,18]$. A total of 14 possible alkaloids have been identified, of which 9 are known. The detailed data are listed in Table 1 and Fig. 3. 


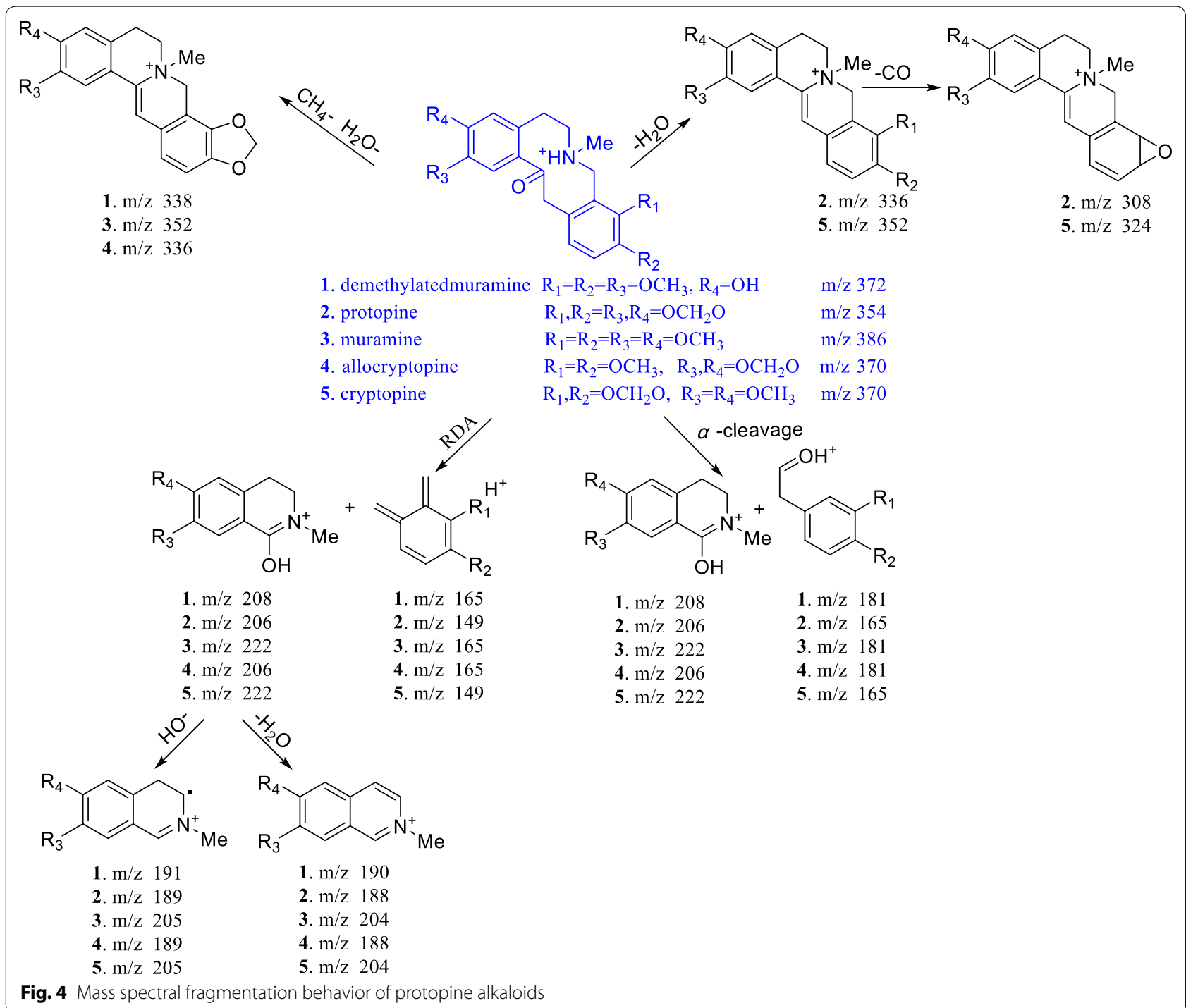

The mass spectral fragmentation behaviors of 9 known and identified alkaloids are shown in Figs. 4, 5, 6 and 7.

The mass spectral cleavage behaviors of protopine alkaloids had the following rules (Fig. 4): The parent nucleus lost one molecule of $\mathrm{H}_{2} \mathrm{O}$ to form a closed fourmembered ring. Protopine alkaloids did not contain large $\pi$ conjugate system, and the parent nucleus was prone to happen RDA cracking and $\alpha$ cleavage reactions, forming small fragment molecules, which would continue to lose hydroxyl or $\mathrm{H}_{2} \mathrm{O}$ moiety to form fragment peaks of $\left[M_{A}-17\right]^{+}$or $\left[M_{A}-18\right]^{+}$, respectively. The mass spectral cleavage rules of benzophenanthridine alkaloids were as follows (Fig. 5): Benzophenanthridine alkaloids were large $\pi$ conjugate system, and the parent nucleus was difficult to fragment. If benzophenanthridine alkaloids contain methylenedioxyl, they would lose carbon monoxide to form a stable ternary oxygen ring. If $O$-dimethoxy group was present in benzophenanthridine alkaloids, the $O$-dimethoxy group would first lose a methyl moiety and then lose hydrogen to form a methylenedioxyl, and the methylenedioxyl will continue to lose one carbon monoxide to form a stable ternary oxygen ring. If benzophenanthridine alkaloids contain 5- or 6-methoxy or methyl groups, the methoxy or methyl groups would be directly lost to form $[\mathrm{M}-31]^{+}$or $[\mathrm{M}-15]^{+}$mass spectral fragments. The cleavage of the dimer mainly occurs at the junction of two alkaloids, to form corresponding precursory alkaloids (Fig. 6).

According to this cleavage rule and the MS/MS fragment peaks, compound $\mathbf{1 2}$ might be a dimer formed by sanguinarine and muramine by the $\mathrm{C}-\mathrm{C}$ single bond, compound 13 might be a dimer formed by chelerythrine and muramine by the $\mathrm{C}-\mathrm{C}$ single bond, compound 14 might be a dimer formed by muramine and a new 


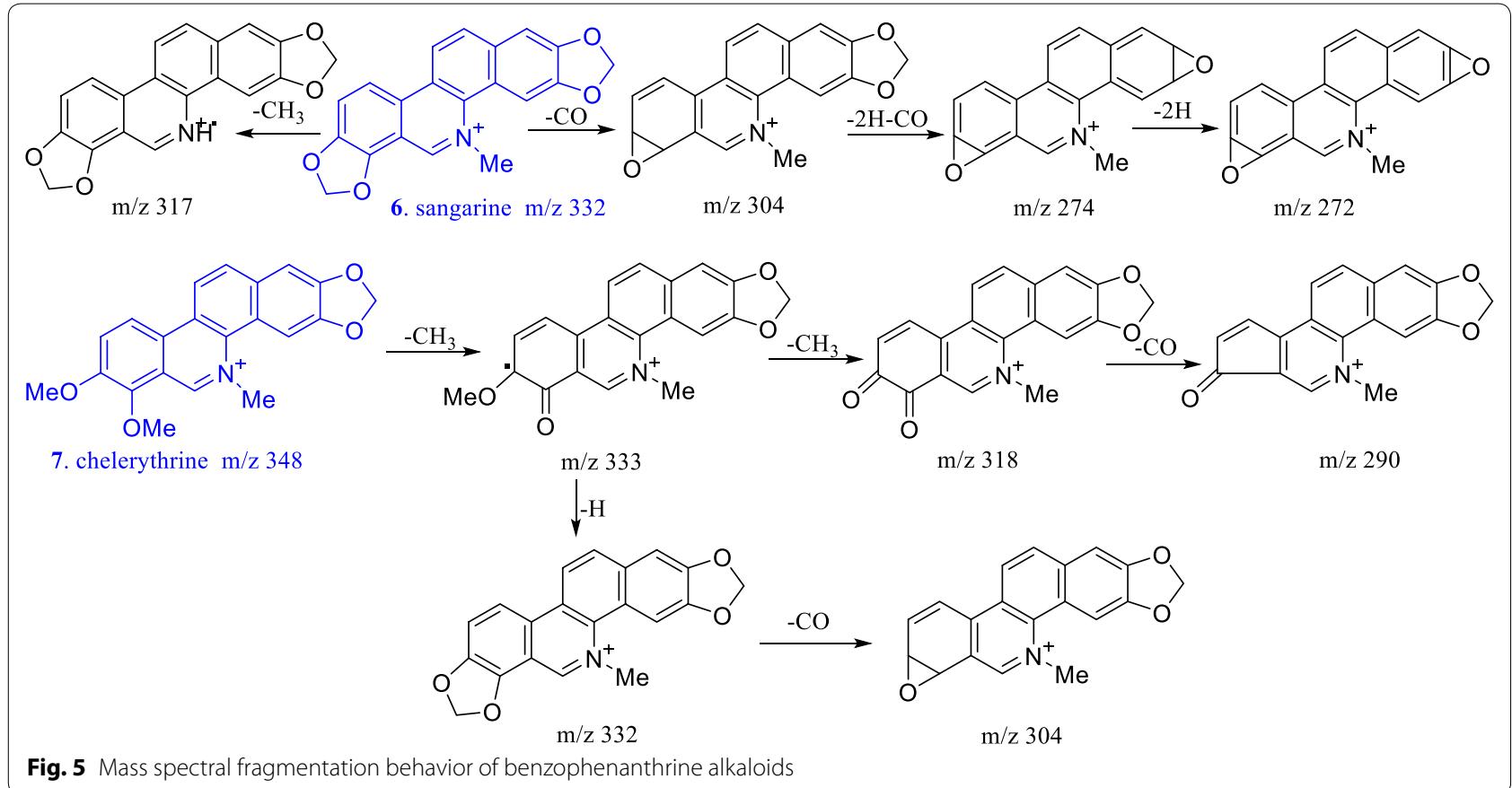

Fig. 5 Mass spectral fragmentation behavior of benzophenanthrine alkaloids

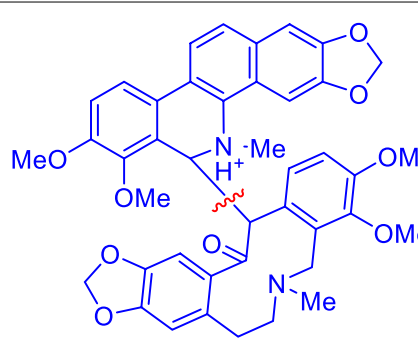<smiles></smiles>

$\mathrm{m} / \mathrm{z} 348$<smiles>COc1ccc(/C=C(/O)[C@H](C)N(C)CCc2cc3c(cc2CCN)OCO3)c(OC)c1OC</smiles>

$\mathrm{m} / \mathrm{z} 369$

8. (+)-macleayin G m/z 717

Fig. 6 Mass spectral fragmentation behavior of dimer alkaloids

benzophenanthridine alkaloid by the $\mathrm{C}-\mathrm{C}$ single bond. To search the related molecular formula from the Scifinder database, 12-14 would be novel compounds. Their exact structures would be determined by NMR after separation and purification. Dihydrobenzophenanthridine alkaloids first lost 6- or 5-substituents to form relatively stable benzophenanthridine alkaloids, and the following fragment rule was consistent with that of benzophenanthridine alkaloids (shown in Fig. 7). The cleavage rules were helpful to identify the characteristic alkaloids in $M$. microcarpa by LC-MS method.
NMR data of compounds 2 and 7

Two major alkaloids, protopine and chelerythrine, were isolated and prepared from M. microcarpa for later activity testing.

Protopine (2) was isolated as colorless square crystal in $\mathrm{CH}_{2} \mathrm{Cl}_{2}: \mathrm{MeOH}(1: 1) .{ }^{1} \mathrm{H} \mathrm{NMR}\left(400 \mathrm{MHz}, \mathrm{CDCl}_{3}\right)$ $\delta$ : $6.90(1 \mathrm{H}, \mathrm{s}, \mathrm{H}-1), 6.69(1 \mathrm{H}, \mathrm{d}, J=7.8 \mathrm{~Hz}, \mathrm{H}-12), 6.66$ $(1 \mathrm{H}, \mathrm{d}, J=7.8 \mathrm{~Hz}, \mathrm{H}-11), 6.64(1 \mathrm{H}, \mathrm{s}, \mathrm{H}-4), 5.95(2 \mathrm{H}, \mathrm{s},-$ $\left.\mathrm{OCH}_{2} \mathrm{O}-2,3\right), 5.92\left(2 \mathrm{H}, \mathrm{s},-\mathrm{OCH}_{2} \mathrm{O}-9,10\right), 3.78(2 \mathrm{H}$, br s, H-13), 3.58 (2H, br s, H-8), 2.2-3.2 (4H, br s, H-5, 6), 1.91 $\left(3 \mathrm{H}, \mathrm{s}, \mathrm{N}-\mathrm{CH}_{3}\right) .{ }^{13} \mathrm{C} \mathrm{NMR}\left(100 \mathrm{MHz}, \mathrm{CDCl}_{3}\right) \delta: 108.3$ 
<smiles>COc1cc2c(c3c1OCO3)-c1ccc3cc4c(cc3c1[NH2+]C4)OCO2</smiles><smiles>COc1cc2c(c3c1-c1ccc4cc5c(cc4c1[NH+](C)C3)OCO5)OCO2</smiles><smiles></smiles>

9. dihydrochelirubine $\mathrm{m} / \mathrm{z} 364$

$\mathrm{m} / \mathrm{z} 348$

$\mathrm{m} / \mathrm{z} 348$<smiles></smiles>

$\mathrm{m} / \mathrm{z} 334$<smiles>COC1=CC2OC2c2c[n+](C)c3c4c(ccc3c21)C=C1OC1C4</smiles>

$\mathrm{m} / \mathrm{z} 306$

Fig. 7 Mass spectral fragmentation behavior of dihydrobenzophenanthrine alkaloids

Table 2 In vitro antiproliferative activities

\begin{tabular}{llcc}
\hline Compounds & $\mathbf{H L}-\mathbf{6 0} \mathrm{IC}_{\mathbf{5 0}}(\boldsymbol{\mu m})$ & $\mathbf{A - 5 4 9} \mathbf{I C}_{\mathbf{5 0}}(\boldsymbol{\mu m})$ & MCF-7 IC $_{\mathbf{5 0}}(\boldsymbol{\mu m})$ \\
\hline Protopine & 6.68 & 20.47 & 22.59 \\
Chelerythrine & 6.68 & 5.37 & 5.26 \\
$5-\mathrm{Fu}$ & 3.10 & 1.80 & 16.68 \\
\hline
\end{tabular}

(C-1), 146.5 (C-2), 148.1 (C-3), 110.6 (C-4), 132.9 (C-4a), 31.9 (C-5), 57.9 (C-6), 50.9 (C-8), 118.0 (C-8a),146.0 (C-9), 146.1 (C-10), 106.9 (C-11), 125.2 (C-12), 129.1 (C-12a), 46.6 (C-13), 195.1 (C-14), 136.3 (C-14a), 101.3 ($\left.\mathrm{OCH}_{2} \mathrm{O}-2,3\right), 101.0\left(-\mathrm{OCH}_{2} \mathrm{O}-9,10\right), 41.6\left(\mathrm{~N}-\mathrm{CH}_{3}\right)$. The structure was identified by comparison of the NMR data with literature [19].

Chelerythrine (7) was yellow powder. ${ }^{1} \mathrm{H} \quad \mathrm{NMR}$ (400 MHz, CD 3 OD) $\delta: 9.99(1 \mathrm{H}, \mathrm{s}, \mathrm{H}-6), 8.71(1 \mathrm{H}, \mathrm{d}$, $J=9.0 \mathrm{~Hz}, \mathrm{H}-10), 8.68(1 \mathrm{H}, \mathrm{d}, J=9.2 \mathrm{~Hz}, \mathrm{H}-11), 8.24(1 \mathrm{H}$, d, $J=9.0 \mathrm{~Hz}, \mathrm{H}-9), 8.23(1 \mathrm{H}, \mathrm{d}, J=9.2 \mathrm{~Hz}, \mathrm{H}-12), 8.21$ $(1 \mathrm{H}, \mathrm{s}, \mathrm{H}-4), 7.59(1 \mathrm{H}, \mathrm{s}, \mathrm{H}-1), 6.28\left(2 \mathrm{H}, \mathrm{s},-\mathrm{OCH}_{2} \mathrm{O}-\right.$ 2,3), $4.30\left(3 \mathrm{H}, \mathrm{s}, 7-\mathrm{OCH}_{3}\right), 4.15\left(3 \mathrm{H}, \mathrm{s}, 8-\mathrm{OCH}_{3}\right), 5.01$ $\left(3 \mathrm{H}, \mathrm{s}, \mathrm{N}-\mathrm{CH}_{3}\right),{ }^{13} \mathrm{C} \mathrm{NMR}\left(100 \mathrm{MHz}, \mathrm{CD}_{3} \mathrm{OD}\right) \delta: 107.1$ (C-1), 151.8 (C-2), 150.8 (C-3), 105.1 (C-4), 121.9 (C-4a), 132.6 (C-4b), $52.9\left(\mathrm{~N}-\mathrm{CH}_{3}\right), 152.1$ (C-6), 119.9 (C-6a), 147.6 (C-7), 151.8 (C-8), 127.5 (C-9), 121.0 (C-10), 130.2 (C-10a), 127.2 (C-10b), 119.5 (C-11), 132.7 (C-12), 134.4 (C-12a), $104.3\left(-\mathrm{OCH}_{2} \mathrm{O}-2,3\right), 62.8\left(7-\mathrm{OCH}_{3}\right)$, $57.6\left(8-\mathrm{OCH}_{3}\right)$. According to related literatures [20, 21] and NMR data, the compound was determined as chelerythrine.

\section{Cytotoxic activity in vitro}

Compounds 2 and 7 exhibited potent cancer cell growth inhibitory activities against HL-60, A-549, and MCF-7 cancer cell lines. The results are summarized in Table 2.

\section{Antiangiogenic activity in vivo}

In order to confirm that protopine and chelerythrine were associated with inhibition of tumor angiogenesis, we used a transgenic zebrafish model to evaluate the antiangiogenesis effects. Transgenic zebrafish embryos at $24 \mathrm{hpf}$ treated with protopine and chelerythrine for $48 \mathrm{~h}$ showed a dose-dependent inhibition of ISV formation. The inhibitory effect of different doses of sample on intersegmental vessel (ISV) formation in zebrafish embryos were shown in Fig. 8 and Table 3. But there were no significant difference in the total length and morphology of ISVs between the treatment group and the control group. All the young fish in each $100 \mu \mathrm{g} / \mathrm{mL}$ sample group died. From these results, we could speculate that the antitumor effects of the samples were not achieved by inhibiting the vascular growth mechanism.

\section{Conclusions}

In this paper, we rapidly and conveniently qualitative analyze alkaloids from $M$. microcarpa by UHPLC-QTOF-MS using accurate mass weight and characteristic fragment ions, and combining with their cleavage rules. Some unknown compounds were discovered through this simple and sensitive method. The study on the cleavage rules of these alkaloids is helpful to identify the characteristic alkaloids by LC-MS method, and identify the structural types of alkaloids in $M$. microcarpa. The two major alkaloids of $M$. microcarpa, protopine and chelerythrine, exhibited potent cancer cell growth inhibitory activities in vitro, but they showed almost no antiangiogenic activity in transgenic zebrafish vivo model. However, the structure and bioactivity screening of new natural products from $M$. microcarpa still need further study, which is an integral part of drug discovery progress. 

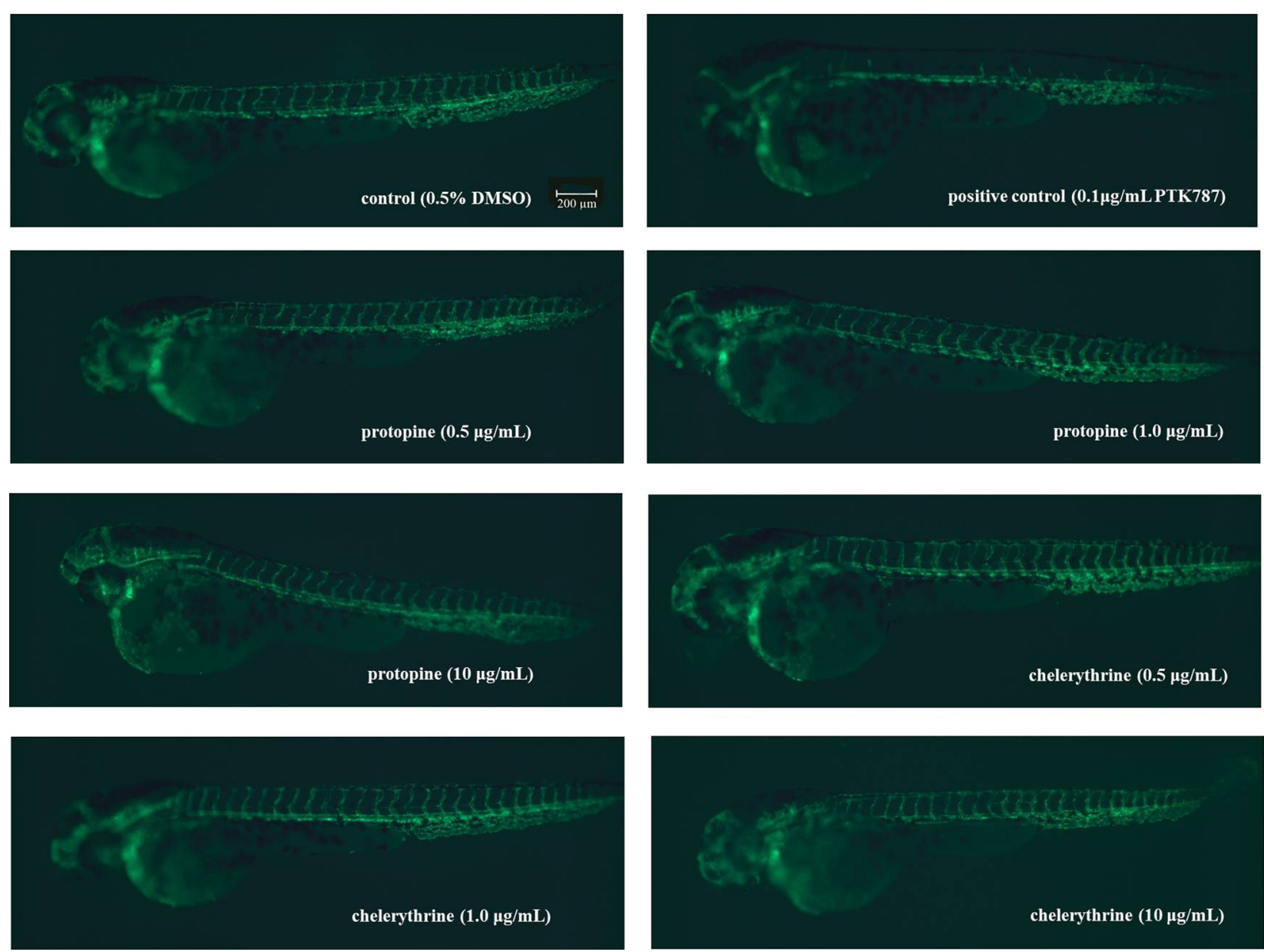

Fig. 8 In vivo antiangiogenic effects of protopine and chelerythrine in transgenic zebrafish

Table 3 Total length of ISV of zebrafish in different treatment groups

\begin{tabular}{lcl}
\hline Group & Total length of ISV $(\boldsymbol{\mu m})$ & $P$ \\
\hline Control $(0.5 \% \mathrm{DMSO})$ & $3021.07 \pm 359.8$ & - \\
Positive control $(0.1 \mu \mathrm{g} / \mathrm{mL}$ PTK787) & $700.08 \pm 214.2^{* *}$ & 0.006 \\
Protopine $(0.5 \mu \mathrm{g} / \mathrm{mL})$ & $2946.44 \pm 403.7$ & 0.880 \\
Protopine $(1 \mu \mathrm{g} / \mathrm{mL})$ & $2950.27 \pm 378.9$ & 0.881 \\
Protopine $(10 \mu \mathrm{g} / \mathrm{mL})$ & $2818.69 \pm 407.4$ & 0.688 \\
Chelerythrine $(0.5 \mu \mathrm{g} / \mathrm{mL})$ & $2952.11 \pm 489.4$ & 0.903 \\
Chelerythrine $(1 \mu \mathrm{g} / \mathrm{mL})$ & $3065.54 \pm 304.9$ & 0.915 \\
Chelerythrine $(10 \mu \mathrm{g} / \mathrm{mL})$ & $3091.49 \pm 525.6$ & 0.906 \\
\hline
\end{tabular}

** Comparison to control group $P<0.05$

\section{Abbreviations}

UHPLC-Q-TOF-MS: ultra high performance liquid chromatography/quadrupole-time-of-fight mass spectrometry; NMR: nuclear magnetic resonance; $\mathrm{HL}$ 60: the human leukaemia cell line; MCF-7: the human breast cancer cell line; A-549: the human lung adenocarcinoma cell line; MTT: 3-(4,5-dimethylthiazol)2,5-diphenyltetrazolium bromide; LC/MS: liquid chromatograph/mass spectrometer; TLC: thin layer chromatography; LC: liquid chromatograph; UHPLC: ultra high performance liquid chromatography; ESI: electrospray ionization; MS: mass spectrometry; $\mid C_{50}$ : the concentration of drug required to inhibit cell growth by $50 \%$ compared with untreated control; ISVs: intersegmental vessels; $\mathrm{m} / \mathrm{z}$ : mass-to-charge ratio.

\section{Acknowledgements}

We thank Biology Institute of Shangdong Academy of Sciences for antiangiogenic activity test using transgenic zebrafish. We gratefully acknowledge Mr. Changshui Wang, Department of Analytical Testing Center, Jining High-tech Zone Science Park, for measurement of the NMR data.

\section{Authors' contributions}

CMS made significant contributions to conception, design, experimentation, acquisition and interpretation of data and writing of manuscript. JAW collected and identified of Macleaya microcarpa (Maxim.) Fedde. BJL made isolation, structure identification of compounds, and their cytotoxic activity test. LD, QBW and HYW conducted antiangiogenic activity test using transgenic zebrafish, and quality control for lab work. FPZ extracted medicinal material. QR guided the qualitative analysis alkaloids by UHPLC-Q-TOF-MS, and took charge in manuscript revision. $\mathrm{HMH}, \mathrm{FPZ}$ and QR guided and designed experiments. All authors read and approved the final manuscript.

\section{Funding}

The collection, extraction, and separation of fruits of M. microcarpa were funded by the National Natural Science Foundation of China (Grant No. 31800282). The NMR data testing was supported by Postdoctoral Science 
Foundation of China (Grant No. 2018M642604). The analysis of alkaloids from fruits of M. microcarpa by UHPLC-Q-TOF-MS was funded by Natural Science Foundation of Shandong Province (Grant No. ZR2017LC003). Cytotoxic activity in vitro and antiangiogenic activity in vivo were funded by Jining Medical University National Natural Science Foundation Nurture Project (Grant No. JYP 201716).

\section{Availability of data and materials}

The datasets used and/or analysed during the current study are available from the corresponding author on reasonable request.

\section{Competing interests}

The authors declare that they have no competing interests.

\section{Author details}

${ }^{1}$ College of Pharmacy, Jining Medical University, Rizhao 276826, Shandong, China. ${ }^{2}$ Shandong Guangyu Tang Guo Yao Co., Ltd., Jining 272071, Shandong, China. ${ }^{3}$ Key Laboratory of Structure-Based Drug Design \& Discovery, Ministry of Education, Shenyang Pharmaceutical University, Shenyang 110016, Liaoning, China.

Received: 11 August 2019 Accepted: 10 January 2020

Published online: 22 January 2020

\section{References}

1. Chinese Academy of Sciences (1998) Chinese Flora Chronicle Committee. Flora of China. Science and Technology Press, Beijing

2. Yu XL, Gao XL, Zhu ZX, Cao Y, Zhang Q, Tu PF, Chai XY (2014) Alkaloids from the tribe bocconieae (papaveraceae): a chemical and biological review. Molecules 19:13042-13060

3. Li LQ, Huang MY, Shao JL, Lin BK, Shen Q (2017) Rapid determination of alkaloids in Macleaya cordata using ionic liquid extraction followed by multiple reaction monitoring UPLC-MS/MS analysis. J Pharmaceut Biomed 135:61-66

4. Kosina P, Gregorova J, Gruz J, Vacek J, Kolar M, Vogel M, Roos W, Naumann K, Simanek V, Ulrichova J (2010) Phytochemical and antimicrobial characterization of Macleaya cordata herb. Fitoterapia 81:1006-1012

5. Ren $\mathrm{Q}$, Wang YL, Wang ML, Wang HY (2016) Screening and identification of the metabolites in rat urine and feces after oral administration of Lycopus lucidus Turcz extract by UHPLC-Q-TOF-MS mass spectrometry. J Chromatogr B 1027:64-73

6. Song L, Wang J, Gao Q, Ma XJ, Wang YW, Zhang YY, Xun H, Yao X, Tang F (2018) Simultaneous determination of five azadirachtins in the seed and leaf extracts of Azadirachta indica by automated online solid-phase extraction coupled with LC-Q-TOF-MS. Chem Cent J 12:85

7. Sai CM, Li DH, Xue CM, Wang KB, Hu P, Pei YH, Bai J, Jing YK, Li ZL, Hua HM (2015) Two pairs of enantiomeric alkaloid dimers from Macleaya cordata. Org Lett 17:4102-4105
8. Mandrekar N, Thakur NL (2009) Significance of the zebrafish model in the discovery of bioactive molecules from nature. Biotechnol Lett 31:171-179

9. Sai CM, Li DH, Li SG, Han T, Guo YZ, Pei YH, Bai J, Jing YK, Li ZL, Hua HM (2016) Racemic alkaloids from Macleaya cordata: structural elucidation, chiral resolution, and cytotoxic, antibacterial activities. RSC Adv 6:41173-41180

10. Wang F, Hua HM, Pei YH, Chen D, Jing YK (2006) Triterpenoids from the resin of styrax tonkinensis and their antiproliferative and differentiation effects in human leukemia HL-60 cells. J Nat Prod 69:807-810

11. Hu J, Shi XD, Chen JG, Mao X, Zhu L, Yu L, Shi JY (2014) Alkaloids from Toddalia asiatica and their cytotoxic, antimicrobial and antifungal activities. Food Chem 148:437-444

12. Chiavacci E, Rizzo M, Pitto L, Patella F, Evangelista M, Mariani L, Rainaldi $\mathrm{G}$ (2015) The zebrafish/tumor xenograft angiogenesis assay as a tool for screening anti-angiogenic miRNAs. Cytotechnology 67:969-975

13. Lin C, Wu MH, Dong JY (2012) Quercetin-49-O-b-D-glucopyranoside (QODG) inhibits angiogenesis by suppressing VEGFR2-mediated signaling in zebrafish and endothelial cells. PLOS ONE 7:e31708

14. Zhang Q, Li Q, Yu C, Huang X, Yang IH, Cao L, Wu WK, Tan HM (2012) Homocysteine-impaired angiogenesis is associated with VEGF/NEGFR inhibition. Front Biosci E4:2525-2535

15. Huang JL, Liu XB, Zheng YJ, Zou CL, Tang ZS, Zeng JG (2017) Identification of alkaloids in flowers of Macleaya cordata (Willd) R. Br. by UHPLC-QTOF/MS. Mod Chin Med 19:1376-1381

16. Qing ZX, Cheng P, Zeng JG (2013) Research progress on mass spectral fragmentation behaviour of alkaloids of Macleaya cordata. Chin Tradit Herbal Drugs 44:2929-2939

17. Sai CM, Li DH, Li SG, Han T, Guo YZ, Li ZL, Hua HM (2017) LC-MS guided isolation of three pairs of enantiomeric alkaloids from Macleaya cordata and their enantioseparations, antiproliferative activity, apoptosis-inducing property. Sci Reports 7:15410

18. Sai CM, Qin NB, Jia CC, Li DH, Wang KB, Pei YH, Bai J, Li ZL, Hua HM (2016) Macleayine, a new alkaloid from Macleaya cordata. Chin Chem Lett 27:1717-1720

19. Miao F, Yang XJ, Zhou L, Hu HJ, Zheng F, Ding XD, Sun DM, Zhou CD, Sun W (2011) Structural modification of sanguinarine and chelerythrine and their antibacterial activity. Nat Prod Res 25:863-875

20. Seger C, Sturm S, Strasser EM, Ellmerer E, Stuppner $\mathrm{H}(2004){ }^{1} \mathrm{H}$ and ${ }^{13} \mathrm{C} \mathrm{NMR}$ signal assignment of benzylisoquinoline alkaloids from Fumaria officinalis $\mathrm{L}$. (Papaveraceae). Magn Reson Chem 42:882-886

21. Liu DH, Zhang TC, Liu JX, Di DL, Dang Y (2011) Chemical constituents of alkaloids from Dicranostigma leptopodum. Chin Tradit Herbal Drugs 42:1505-1508

\section{Publisher's Note}

Springer Nature remains neutral with regard to jurisdictional claims in published maps and institutional affiliations.

Ready to submit your research? Choose BMC and benefit from:

- fast, convenient online submission

- thorough peer review by experienced researchers in your field

- rapid publication on acceptance

- support for research data, including large and complex data types

- gold Open Access which fosters wider collaboration and increased citations

- maximum visibility for your research: over 100M website views per year

At BMC, research is always in progress.

Learn more biomedcentral.com/submissions 